\title{
Federalism and Breach of the Labor
}

\section{Agreement}

\author{
Donald H. Wollett* and Harry H. Wellington $\dagger$
}

When the Supreme Court of the United States granted certiorari in Association of Westinghouse Salaried Employees $v$. Westinghouse Elec. Corp., ${ }^{1}$ it brought before it for the first time a suit initiated under Section 301 of the Taft-Hartley Act. ${ }^{2}$ In March the Court rendered judgment in the case. ${ }^{3}$ But the niceties of appellate review and the lack of agreement among the Justices prevented the Court from resolving the troublesome problems of federalism raised by the statute.

Section 301 (a) reads:

Suits for violation of contracts between an employer and a labor organization representing employees in an industry affecting commerce as defined in this chapter, or between any such labor organizations, may be brought in any district court of the United States having jurisdiction of the parties, without respect to the amount in controversy or without regard to the citizenship of the parties. ${ }^{4}$

- B.A., University of Chicago, 1941; LI.B., Indiana University School of Law, 1942; Professor of Law, University of Washington.

† A.B., University of Pennsylvania, 1947; LL.B., Harvard University, 1952; Assistant Professor of Law, Stanford University.

1. 347 U.S. 1010 (1954).

2. 61 Srat. 156 (1947), 29 U.S.C. $\$ 185$ (1952).

3. Association of Westinghouse Salaried Employees v. Westinghouse Elec. Corp., 348 U.S. 437 (1955).

4. The remainder of the section provides:

"(b) Any labor organization which represents employees in an industry affecting commerce as defined in this Act and any employer whose activities affect commerce as defined in this Act shall be bound by the acts of its agents. Any such labor organization may sue or be sued as an entity and in behalf of the employees whom it represents in the courts of the United States. Any money judgment against a labor organization in a district court of the United States shall be enforceable only against the organization as an entity and against its assets, and shall not be enforceable against any individual member or his assets.

"(c) For the purposes of actions and proceedings by or against labor organizations in the district courts of the United States, district courts shall be deemed to have jurisdiction of a labor organization (1) in the district in which such organization maintains its principal office, or (2) in any district in which its duly authorized officers or agents are engaged in representing or acting for employee members.

"(d) The service of summons, subpoena, or other legal process of any court of the United States upon an officer or agent of a labor organization, in his capacity as such, shall constitute service upon the labor organization.

"(c) For the purposes of this section, in determining whether any person is acting as an 'agent' of another person so as to make such other person responsible for his acts, the question of whether the specific acts performed were actually authorized or subsequently ratified shall not be controlling." 
On its face this section merely provides a federal forum for actions based upon breach of a collective bargaining agreement. If such is in fact the case, state substantive law, which has traditionally been applied in cases involving the breach of a labor agreement, would continue to be applied.

However, Section 301 (a) generally has been interpreted by the lower federal courts as calling for the resolution of disputes through the application of federal, rather than state, law. ${ }^{6}$ The reason for this tendency is not readily found in the Labor Management Relations Act or in its legislative history. ${ }^{7}$ The interpretation has usually been explained in terms of a presumption of constitutionality. Section 3 or (a), it has been argued, ${ }^{8}$ is a grant of jurisdiction to the federal courts without regard to the existence of diversity of citizenship between the litigants. Therefore, the constitutional basis for federal jurisdiction must be that the case is one "arising under . . . the Laws of the United States. . . ." Prior decisions indicate that a case arises under the laws of the United States only where federal substantive law is an integral part of the plaintiff's cause of action. ${ }^{10}$ To avoid constitutional difficulties,

5. See Witmer, Collective Labor Agreements in the Courts, 48 YaLE L.J. 195 (1938).

6. United Elec. Workers v. Oliver Corp., 205 F.2d 376 (8th Cir. 1953); International Plainfield Motor Co. v. Local 343, UAW-CIO, 123 F. Supp. 683 (D.N.J. 1954); Ludlow Mfg. \& Sales Co. v. Textile Workers Union, 108 F. Supp. 45 (D. Del. 1952); Pepper \& Potter, Inc. v. Local 977, UAW-CIO, 103 F. Supp. 684 (S.D.N.Y. 1952); Textile Workers Union v. Aleo Mfg. Co., 94 F. Supp. 626 (M.D.N.C. 1950); Wilson \& Co., Inc. v. United Packinghouse Workers, 83 F. Supp. 162 (S.D.N.Y. 1949); Colonial Hardwood Flooring Co. v. United Furniture Workers, 76 F. Supp. 493 (D. Md.), affd, 168 F.2d 33 (4th Cir. 1948).

For cases in which courts expressly refused to apply state law, see International Union of Operating Engineers v. Dahlem Constr. Co., 193 F.2d 470 (6th Cir. 1951); ShirleyHerman Co. v. International Hod Carriers, 182 F.2d 806 (2d Cir. 1950); Wajalua Agricultural Co. v. United Sugar Workers, 114 F. Supp. 243 (D. Hawaii 1953).

It would seem that the federal courts would rely, where possible, on the IMRA in fashioning a body of substantive law. See Hamilton Foundry \& Mach. Co. v. International Molders \&: Foundry Workers Union, 95 F. Supp. 35 (S.D. Ohio), affd, 193 F.2d 209 (5th Cir. 1951), cert. denied, 343 U.S. 966 (1952). But there has been some tendency to rely on arbitration decisions. See, e.g., Local 50, Bakery Workers v. General Baking Co., 97 F. Supp. 73 (S.D.N.Y. 1951). For a case in which the court evidently applied regular contract principles, see Bakery Workers v. National Biscuit Co., 177 F.2d 684 (3d Cir. 1949).

7. See discussion at pp. 472-75 infra. See also the opinion of Mr. Justice Franlifurter in Association of Westinghouse Salaried Employees v. Westinghouse Elec. Corp., 348 U.S. $437,443-49$ (1955).

8. See, e.g., Wilson \& Co., Inc. v. United Packinghouse Workers, 83 F. Supp. 162, 165 (S.D.N.Y. 1949); Colonial Hardwood Flooring Co. v. United Furniture Workers, 76 F. Supp. 493, 496 (D. Md.), aff'd, 168 F.2d 33 (4th Cir. 1948); dictum, Schatte v. IATSE, 182 F.2d 158, 164 (9th Cir.), cert. denied, 340 U.S. 827 (1950). See also Shirley-Herman Co. v. International Hod Carriers, 182 F.2d 806, 809 (2d Cir. 1950), in which the court generally approves the discussion in the Wilson case.

9. U.S. Const. Art. III, \$2.

10. See, e.g., Gully v. First Nat. Bank, 299 U.S. 109 (1936). The distinction is often difficult to make. Compare Smith v. Kansas City Title \&: Trust Co., 255 U.S. 180 (1921) (federal cause of action), with American Well Works Co. v. Layne and Bowler Co., 241 
therefore, Section $30 \mathrm{r}$ must be read as requiring the courts to fashion a federal law of labor contracts. There has, however, been some dissent. A few courts, without regard to the constitutional problem, have simply applied state law as if federal jurisdiction were grounded upon diversity of citizenship. ${ }^{11}$ The Westinghouse case indicates that the issue is far from settled.

The district court in the Westinghouse litigation ${ }^{12}$ did not discuss the problem of federalism raised by Section 3or. The union began its suit against Westinghouse under Section 301 and the Federal Declaratory Judgment Act. ${ }^{13}$ It sought a ruling that its collective agreement required Westinghouse to pay some 4,000 employees salary for a day on which they did not work. The union also prayed for damages in favor of the employees so entitled. Westinghouse moved to dismiss the complaint upon the grounds that (I) the union was not the real party in interest; (2) the court lacked jurisdiction over the subject matter; and (3) the complaint failed to state a claim for relief. The district court held for the union on grounds one and two but dismissed the complaint without prejudice, ruling that it failed to state a claim for relief. In the court's opinion, Westinghouse had no duty under the collective agreement to pay wages during voluntary absences, and the union had not alleged that the employees' absences were other than voluntary. ${ }^{14}$

The Court of Appeals for the Third Circuit vacated the order of the district court in a four to three decision and ordered the complaint dismissed for lack of jurisdiction over the subject matter of the action. ${ }^{15}$ The majority stated that the wage provisions of the collective agreement did not become enforceable rights until they were incorporated into the workers' individual employment con-

U.S. 257 (1916) (state cause of action). Sce also Chadbourn and Levin, Original Jurisdiction of Federal Questions, 90 U. OF PA. L. Rev. 639 (1942).

11. E.g., Boeing Airplane Co. v. Aeronautical Industrial Dist., Int'l Ass'n of Machinists, 91 F. Supp. 596 (W.D. Wash. 1950), affd, 188 F.2d 356 (9th Cir.), cert. denied, 342 U.S. 821 (1951). But see Schatte v. IATSE, 182 F.2d 158, 164 (9th Cir.), cert. denied, 340 U.S. 827 (1950), in which the Ninth Circuit apparently reversed its position. See also Paterson Parchment Paper Co. v. International Brotherhood of Paper Makers, 191 F.2d 252 (3d Cir. 1951), cert. denied, 342 U.S. 933 (1952); Mercury Oil Refining Co. v. Oil Workers, 187 F.2d 980 (10th Cir. 1951).

12. Association of Westinghouse Salaried Employees v. Westinghouse Elec. Corp., 107 F. Supp. 692 (W.D. Pa. 1952).

13. 28 U.S.C. $\$ \$ 2201-2$ (1952).

14. Association of Westinghouse Salaried Employees v. Westinghouse Elec. Corp., 107 F. Supp. 692, 696-97 (W.D. Pa. 1952).

15. Association of Westinghouse Salaried Employees v. Westinghouse Elec. Corp., 210 F.2d 623 (3d Cir. 1954). 
tracts. ${ }^{16}$ And since the claims asserted arose out of individual contracts and not out of an agreement between an employer and a union, they were not cognizable under Section 3 or. ${ }^{17}$ More important for the purpose at hand, the court's conclusion concerning the nature of the collective bargaining agreement and the legal effect of its wage provisions was based upon federal, not state, law. ${ }^{18}$

The dissenting judges on the other hand did not disclose the source of the law they applied to the case. Their opinion, however, nowhere indicated that they disagreed with the majority's decision on this question. Their disagreement with the majority was upon another level. They declared that the union did have an interest in the wage terms of the collective agreement sufficient to entitle it to whatever remedy-e.g., a declaratory judgment-was necessary to protect group interests. ${ }^{19}$ The dissenters, however, also agreed with the district court that the union's complaint was defective. $^{20}$

In affirming the decision of the court of appeals ${ }^{21}$ the Supreme Court did not decide whether, as a matter of contract law, the claims against Westinghouse arose out of the collective bargaining agreement. The Court did not reach this question. There was no opinion of the Court in the Westinghouse case. But a majority of the Justices held that the district court had no jurisdiction over the subject matter of the suit because Section 30r simply does not give the federal courts jurisdiction in the type of case before that court. ${ }^{22}$ This holding did not depend on whether the majority or the dissent in the court of appeals was correct in its analysis of the nature of a collective bargaining agreement. Moreover, it did not authoritatively settle whether the court of appeals was right or

16. Id. at 627 .

17. In reaching this conclusion the court recognized that at least some terms of a collective agreement do create legally enforceable rights and duties, e.g., chock-off, lock-out, union shop, runaway shop, arbitration and safety-condition provisions. Id. at 628 . In differentiating between terms that create legally enforceable rights and those that do not, the court asked itself: Whose promises furnish consideration for the employer's promises? Ibid. The employer's promise to check off dues is supported by union promises, e.g., the promise not to strike. Hence, his promise creates a right in the union. The employer's promise to pay wages, however, is supported by the individual employee's performance of work. See ibid.

18. Id. at 625 .

19. Id. at 632-33 (Hastie, J., dissenting).

20. 1d. at 630-34.

21. Association of Westinghouse Salaried Employees v. Westinghouse Elec. Corp., 348 U.S. 437 (1955).

22. Id. at 461 . 
wrong in deciding that federal rather than state law determines the rights and liabilities arising from a labor agreement. Six of the eight Justices participating in the case did, however, disclose their position on this last question.

Mr. Justice Frankfurter announced the judgment of the Court and wrote an opinion in which Mr. Justice Burton and Mr. Justice Minton joined. For them, the judgment of the Court was the result of at least two related and intermediate conclusions. First: That the language and legislative history of the Taft-Hartley Act in general and Section 301 in particular preclude the conclusion that Congress intended Section 301 to be any more than a grant of jurisdiction. ${ }^{23}$ Second: This is so even though a purely jurisdictional construction of Section 301 poses a serious question as to the validity of the statute under the Constitution. ${ }^{24}$ However, Mr. Justice Frankfurter avoided the constitutional problem-and the necessity of holding Section 3 or jurisdictional- "through the orthodox process of limiting the scope of doubtful legislation," by reading the statute as not covering a suit by the union for employees' wages. He buttressed his position by saying:

There was no suggestion that Congress, at a time when its attention was directed to congestion in the federal courts, particularly in the heavy industrial areas, intended to open the doors of the federal courts to a potential flood of grievances based upon an employer's failure to comply with terms of a collective agreement relating to compensation, terms peculiar in the individual benefit which is their subject matter and which, when violated, give a cause of action to the individual employee. ${ }^{26}$

In a short separate opinion, the Chief Justice, joined by Mr. Justice Clark, concurred in the conclusion that Congress had not intended the federal courts to have jurisdiction in such a case. ${ }^{27}$ The concurring Justices did not disclose their reason for reading Section 3 or so narrowly, and summarily refused to undertake such a task although the language and legislative history of Section 301 do not make their interpretation obvious. They concluded it was "unnecessary .... either to make labor policy or to raise constitutional issues."

\footnotetext{
23. Id. at 441-49.

24. Id. at $449-52$.

25. Id. at 459 .

26. Id. at 460 .

27. Id. at 461 .

28. Ibid.
} 
Mr. Justice Reed also concurred in the disposition of the case, ${ }^{29}$ but apparently on the ground expounded by the majority of the court of appeals that the wage claim did not arise out of the collective agreement but rather out of the employees' contracts of hire. ${ }^{30}$ Moreover, he, like the court of appeals, apparently conceived of Section $30 r$ as requiring the federal courts to fashion and apply federal substantive law. ${ }^{31}$

While the opinion of Mr. Justice Reed is not perfectly clear on the point, a substantive interpretation of Section 301 (a) is patent in the dissenting opinion of Mr. Justice Douglas, in which Mr. Justice Black concurred. ${ }^{32}$ The dissenters thought, moreover, that as a matter of federal law the union was properly asserting a right stemming from the collective agreement and maintainable under Section $301 .^{33}$

Thus, the Westinghouse case failed to settle whether Section 3 or does more than provide a federal forum for actions based upon breach of a collective agreement. Of the six Justices who expressed opinions on the subject, three concluded that the statute is merely jurisdictional, i.e., it provides a federal forum wherein the substantive rights of the litigants are determined in accordance with state law. Two others, however, construed the statute as substantive, i.e., it provides a federal forum wherein the substantive rights of the litigants are determined in accordance with federal law, fashioned by the federal courts. A third appeared to agree with this construction.

When the Court does decide the question, a substantive interpretation will have a decidedly different effect upon state power than a jurisdictional interpretation. In this Article we propose to examine the impact upon state power of both a substantive and a jurisdictional construction of Section 3or, and to suggest how the issue may ultimately be resolved.

\section{The Implicattons of a Substanttve Interpretatton}

\section{A. In General}

If the Court adopts the view that Section 30 creates a federal cause of action and requires the fashioning of federal substantive
29. Ibid.
30. 1d. at 464 .
31. Id. at 463-64.
32. Id. at 465 .
33. Id. at 465-66. 
law, the power of the states to enforce collective agreements will be curtailed. The extent of curtailment is, of course, speculative. The federal courts may, where the statute whose commands they are carrying out does not require uniformity, adopt as federal law the rules of the states in which they happen to be sitting. ${ }^{34}$ If so, the impact on state power will be relatively small. However, the courts are not likely to follow such a course with respect to Section $30 r$. Aside from the constitutional consideration, the principal justification for imputing to Congress the intention that federal law should be applicable to suits under Section $30 \mathrm{r}$ is that a uniform substantive law ought to apply in this area of labor relations. ${ }^{35}$ The courts may draw on state law to resolve particular issues, but only when they adjudge that the application of state law does not clash with the uniform national policy which Congress must have had in mind when, by hypothesis, it created the federal substantive right. $^{36}$

Consistent with this rationale, some of the federal courts which have given Section 301 a substantive reading have fashioned rules without regard to state law. ${ }^{37}$ And in at least one case the rule established by the federal court was in direct conflict with the relevant state rule. ${ }^{38}$ Moreover, Mr. Justice Douglas, in his dissenting opinion in the Westinghouse case, implied that the new law is to be uniform throughout the federal system. ${ }^{39}$ And in the opening paragraph of his dissent he revealed some of the sources of this law:

I agree with Mr. Justice Reed that Congress in the Taft-Hartley Act created federal sanctions for collective bargaining agreements, made the cases and controversies concerning them justiciable questions for the federal courts, and permitted those courts to fashion from the federal statute, from state law, or from other germane sources, federal rules for the construction and interpretation of those collective bargaining agreements. ${ }^{10}$

34. See, e.g., Royal Indemnity Co. v. United States, 313 U.S. 289 (1941) (damages owed the United States by private party for delayed payment of contractual obligation fixed by New York law).

35. See Association of Westinghouse Salaried Employees v. Westinghouse Elec. Corp., 348 U.S. 437, 461-65 (1955) (Reed, J., concurring opinion).

36. See Cox, Grievance Arbitration in the Federal Courts, 67 Harv. L. Rev, 591, $600-601$ (1954).

37. See, e.g., Association of Westinghouse Salaried Employees v. Westinghouse Elec. Corp., 210 F.2d 623 (3d Cir. 1954); International Union of Operating Engineers v. Dahlem Constr. Co., 193 F.2d 470 (6th Cir. 1951).

38. Shirley-Herman Co. v. International Hod Carriers, 182 F.2d 806 (2d Cir. 1950).

39. Association of Westinghouse Salaried Employees v. Westinghouse Elec. Corp., 348

U.S. 437, 465-67 (1955).

40. Id. at 465 . 
But what happens to state sanctions after the new federal law has been fashioned from germane sources? The question can be sharply presented by supposing that a complaint, making no reference to Section 301 but purporting to be grounded upon state law, is filed in a state court. If a substantive interpretation of Section 301 does presuppose the need for a uniform construction of the terms of a labor agreement irrespective of where it was negotiated or performed, such an interpretation would seem to preclude the survival of a state cause of action under possibly confficting state law. The existence of a separate state action would undercut the paramount federal policy of uniformity. Quite apart from this, the existence of a state cause of action independent of a federal cause of action would eliminate a rather more essential type of uniformity, namely, a usual if not always certain uniformity in result irrespective of whether the parties litigate in a federal or state forum. Put another way, if there is a state as well as a federal cause of action, the primary contractual rights and duties of labor and management will be simultaneously regulated by two relatively independent bodies of possibly conflicting law. In another sphere this was an evil of Swift v. Tyson. ${ }^{41}$ The state court should, therefore, assuming it has any jurisdiction at all, follow federal law whenever the action for breach might have been initiated in a federal court under Section 30x. There can be only one cause of action between employers and unions in industries affecting commerce, and by hypothesis it is federal. ${ }^{22}$

\section{B. State Court Jurisdiction}

\section{Power to Enforce the Federal Cause of Action. Section}

41. 16 Pet. 1 (U.S. 1842).

42. For cases in which the court apparently so conciuded, see Fay v. Ameriean Cystoscope Makers, Inc., 98 F. Supp. 278 (S.D.N.Y. 1951); Fitzgerald v. Dictograph Products, Inc., 28 L.R.R.M. 2611 (N.Y. Sup. Ct. 1951). For analogous situations in which the courts have reached similar conclusions, see Direct Transit Lines v. Mackey, 34 L.R.R.M. 2572 (W.D. Mich. 1954), writ of mandamus denied, 219 F.2d 699 (6th Cir. 1955) (complaint which alleges facts that constitute an unfair labor practice under the LMRA raises a federal question and is removable, even though it purports to be grounded on state law); S. E. Overton Co. v. Teamsters Union, 115 F. Supp. 764 (W.D. Mich. 1953) (same); Direct Transit Lines, Inc. v. Local Union 406, 30 L.R.R.M. 2471 (W. D. Mich. 1952), petition for mandamus directing remand denied, 199 F.2d 89 (6th Cir. 1952) (complaint which alleges facts that constitute a violation of $\$ 303$ of Taft-Hartley raises a federal question and is removable, even though it purports to be grounded on state law). See also Pocahontas Terminal Corp. v. Portland Bldg. \& Constr. Trade Council, 93 F. Supp. 217 (D. Me. 1950), for general statement as to the effect of the Labor Management Relations Act.

For a case in which a federal court reached the contrary conclusion, see Associated Tel. Co. v. Communications Workers, 114 F. Supp. 334 (S.D. Cal. 1953). See also Castle \&. Cooke Terminals v. Local 137, IIWU, 110 F. Supp. 247, 249-50 (D. Hawaii 1953), in which the court criticizes the Fay case. 
301 (a) itself is silent on the matter of state court jurisdiction, and no firm inferences can be drawn from other parts of the statute. Section $303^{43}$ makes tortious certain activities which also constitute unfair labor practices. It further provides that an injured party is entitled to sue for damages. This section is clearly substantive and expressly confers jurisdiction on state as well as federal courts. Hence, it may be argued that the silence of Section 301 as to state court jurisdiction implies that such jurisdiction has been withheld.

However, a contrary argument may be maintained just as plausibly. Section 303 provides judicial remedies for certain unfair labor practices-matters which are otherwise within the exclusive jurisdiction of the National Labor Relations Board. Congress, therefore, expressly conferred jurisdiction upon state courts in order to make it clear that the usually exclusive jurisdiction of the Board had been extended to them as well as to the federal courts. Enforcement of the labor agreement, however, is not within the exclusive jurisdiction of the Board. In recent years the Supreme Court has sharply restricted the power of the states, through courts or administrative agencies, to handle matters which are within the exclusive jurisdiction of the NLRB-e.g., representation questions and federal unfair labor practices. ${ }^{44}$ But these decisions have no bearing on the question whether state courts have jurisdiction to enforce a federal cause of action for breach of a collective bargaining agreement. While conduct which constitutes breach of a labor agreement may coincidentally be an unfair labor practice under the LMRA, ${ }^{45}$ the failure to perform a contractual commitment is not necessarily such an illegal practice, ${ }^{46}$ and the Board has es-

43. 61 StaT. 158 (1947), 29 U.S.C. $\$ 187$ (1952).

44. See, e.g., Weber v. Anheuser-Busch, Inc., 348 U.S. 468 (1955); Garner v. Teamsters Union, 346 U.S. 485 (1953) (unfair labor practices); Plankinton Packing Co. v. Wisconsin Employment Relations Bd., 338 U.S. 953 (1950), reversing per curiam 255 Wis. 285, 38 N.W.2d 688 (1949) (same); La Crosse Tel. Corp. v. Wisconsin Employment Relations Bd., 336 U.S. 18 (1949) (representation); Bethlehem Steel Co. v. New York State Labor Relations Bd., 330 U.S. 767 (1947) (same). For a situation in which a state board may assume jurisdiction, see Algoma Plywood \& Veneer $\mathrm{C}$. v. Wisconsin Employment Relations Bd., 336 U.S. 301 (1949) (state board remedying of an unfair labor practice valid when not in conflict with the NLRA). But see New York State Labor Relations Bd. v. Wags Transp. System, Inc., 130 N.Y.S.2d 731 (Sup. C.), aff'd, 284 App. Div. 883, 134 N.Y.S.2d 603 (1st Dept. 1954), in which the court declared the state board could not assume jurisdiction over an unfair labor practice dispute unless there be a clear showing that the NLRB would not have assumed jurisdiction.

45. In Boeing Airplane Co. v. NLRB, 174 F.2d 988 (D.C. Cir. 1949), the court in refusing to enforce a Board order held that a strike during the life of an agreement containing a no-strike promise also violated the notice provisions of $\S 8(\mathrm{~d})$.

46. NLRB v. Potlatch Forests, Inc., 189 F.2d 82 (9th Cir. 1951); Textron Puerto Rico, 107 N.L.R.B. 583 (1953); Old Line Life Ins. Co., 96 N.L.R.B. 499 (1951). 
chewed the role of policing labor agreements and providing remedies for violation of their terms. ${ }^{47}$ Congress has seen fit to vest jurisdiction in the district courts to hear actions for a breach of a labor agreement, even though the decisions reached might produce incidental intrusions on NLRB jurisdiction, ${ }^{48}$ and there would seem to be no reason to suspect that Congress was concerned about similar interference resulting from state court enforcement of the federal cause of action. ${ }^{40}$ Thus, since state courts have jurisdiction over a cause of action arising out of an act of Congress unless such jurisdiction has been expressly or impliedly withheld, ${ }^{50}$ there was no reason to provide for concurrent state court jurisdiction in Section 30 . $^{51}$

Finally, the legislative history of Section $30 \mathrm{r}$ is consistent with the conclusion that state courts do have jurisdiction to enforce the federal cause of action. A proposal to make breach of a collective bargaining agreement an unfair labor practice was dropped from the bills which subsequently became the Taft-Hartley Act, ${ }^{22}$ with this comment:

Once the parties have made a collective bargaining contract the enforcement of that contract should be left to the usual processes of the law and not to the National Labor Relations Board. ${ }^{53}$

Since "the usual processes of the law" include enforcement in state tribunals, this explanation seemed to manifest a congressional un-

47. "[T] $\mathrm{T}$ he stability of labor relations which the statute seeks to accomplish . . . depends upon the channelization of the collective bargaining relationship within the procedures of a collective bargaining agreement. By encouraging the utilization of such procedures in this case, we believe that statutory policy will best be effectuated. Affirmative Board action would on the other hand put the Board in the position of policing collective bargaining agreements, a role we are unwilling to assume." Crown Zeilerbach Corp., 95 N.L.R.B. 753,754 (1951).

48. The federal courts will take jurisdiction under $\S 301$ (a) even though the conduct which allegedly constitutes a breach is also an unfair labor practice. Textile Workers Union v. Arista Mills Co., 193 F.2d 529 (4th Cir. 1951); Reed v. Fawick Airflex Co., 86 F. Supp. 822 (N.D. Ohio 1949). In Modine Mfg. Co. v. Grand Lodge Int'l Ass'n of Machinists, 216 F.2d 326 (6th Cir. 1954), the court assumed jurisdiction even though the plaintiff did not allege breach of contract originally but later amended. For a case in which the court said it would not take jurisdiction over an unfair labor practice, see Reinauer Transp. Cos. v. United Marine Div., 112 F. Supp. 940 (S.D.N.Y. 1953).

49. It does not follow, of course, that the states will be free to ignore the substantive rules developed by the NLRB to implement the policies of the LMRA. Indeed, since these rules will presumably be a major source of the federal substantive law, the state courts will be constrained to follow them.

50. See Claflin v. Houseman, 93 U.S. 130 (1876).

51. It should be noted that the silence of $\S 301$ as to state court jurisdiction is also consistent with a jurisdictional interpretation of the section.

52. H.R. 3020, 80th Cong., Ist Sess. \$2(11)(A) (1947); H.R. 3020, as passed Senate, 80th Cong., 1st Sess. $\$ \$ 8(a)(6), 8(\mathrm{~b})(5)$ (1947); CoNF. REP. No. 510, 80th Cong., 1st Sess. 42 (1947).

53. Conf. Rep. No. 510, 80th Cong., 1st Sess. 42 (1947). 
derstanding that the state and federal courts and state agencies would continue to handle the enforcement of labor agreements." And there is nothing else in the statute's legislative history inconsistent with such a conclusion. It seems likely, therefore, that the states will retain jurisdiction to enforce the federal cause of action even though a substantive view of Section 301 is adopted. ${ }^{55}$

2. Power to Provide Remedies Not Available in the Federal Courts. Whether the states can provide remedies other than those available in the federal courts is a more difficult question. Before reaching that question, however, it is essential to determine, by way of introduction, what remedies a claimant can obtain in a federal court.

In terms, Section 301 provides only the remedy of damages. Subsection (b), the only part of the section which refers to remedies, speaks solely of money judgments and specifies that they are enforceable only against the union as an entity-i.e., against organization assets.

That other remedies are available in a federal court is doubtful. Where the propriety of union self-help is in issue-e.g., where the complaint alleges breach of a no-strike promise-most federal courts have held that the controversy arises out of a "labor dispute" as defined by Section I3 of the Norris-LaGuardia Act, ${ }^{56}$ and that Section 4 of that statute ${ }^{67}$ prohibits the issuance of an injunction. ${ }^{i s}$ It would also seem that the federal courts cannot issue an injunction where the propriety of employer conduct is in question, (1950).

54. See Cox and Seidman, Federalism and Labor Relations, 64 Harv. L. Rev. 211, 245

55. For eases in which the courts have so held, see General Elec. Co. v. UAW-CIO, 93 Ohio App. 139, 108 N.E.2d 211 (1952), appeal dismissed, 158 Ohio St. 555, 110 N.E.2d 424 (1953); General Bldg. Contractors' Ass'n v. Local 542, 370 Pa. 73, 87 A.2d 250, 32 A.L.R.2d 822 (1952).

56. 47 STAT. 73 (1932), 29 U.S.C. $\$ 113$ (1952).

57. 47 STAT. 70 (1932), 29 U.S.C. \$ 104 (1952).

58. W. L. Mead, Inc. v. Teamsters Union, 217 F.2d 6 (1st Cir. 1954); Sound Lumber Co. v. Lumber \& Sawmill Workers, 34 L.R.R.M. 2494 (N.D. Cal. 1954); Duris v. Phelps Dodge Copper Products Corp., 87 F. Supp. 229 (D.N.J. 1949).

In Alcoa S.S. Co. v. McMahon, 173 F.2d 567 (2d Cir.), cert. denied, 338 U.S. 821 (1949), the court of appeals stated that an injunction was not available as a remedy against employees for their breach of the contract because the breach remained a "controversy concerning the terms and conditions of employment" and hence a "labor dispute" despite a declaratory judgment that the employees had violated the contract. Presumably the court would have reached the same result if the merits of the controversy had been settled by an agreement, arbitration or a labor relations board. Subsequently the employers brought a successful damage action. Alcoa S.S. Co. v. Conerford, $17 \mathrm{CCH}$ LAs. Cas. $\$ 65,480$ (S.D.N.Y. 1949). The assumption that a controversy over the meaning of a labor agreement is a labor dispute underlay all of the opinions in United States v. United Mine Workers, 330 U.S. 258 (1947). 
unless the plaintiff can make out the case required by Section 7 of the Norris-LaGuardia Act. ${ }^{68}$ The practical result is that a federal

59. The Norris-LaGuardia Act was doubtless conceived as a protective device for unions, but it may also protect an employer. The language of the statute itself suggests the possibility.

The Statute: Under $\$ 13(a), 47$ STAT. 73 (1932), 29 U.S.C. $§ 113($ a) (1952), a case grows out of a labor dispute when it involves conflicting or competing interests in a labor dispute-a controversy concerning terms or conditions of employment-between persons participating or interested therein. Section 13(b), 47 STAT. 73 (1932), 29 U.S.C. \$ 113(b) (1952), provides that a person or association is a person participating or interested in a labor dispute if relief is sought against him or it, and he or it is either engaged in the same industry in which the dispute occurs or is a member, officer or agent of any association of employers or employees engaged in such industry. This definition would clearly seem to cover an employer who is a defendant in a dispute over the meaning of a labor contract it has entered into with the union representing its employees.

The Cases: Considerable authority supports the proposition that the Norris-LaGuardia Act is applicable in the federal courts to an action for injunctive relief brought by a union or employees against an employer in a case growing out of a labor dispute. In Amazon Cotton Mill Co. v. Textile Workers Union, 167 F.2d 183 (4th Cir. 1948), for example, the union brought an action to enjoin the employer from refusing to bargain collectively. The court in reversing a judgment granting an interlocutory injunction held that the Labor Management Relations Act of 1947, 61 SтAт. 136 (1947), 29 U.S.C. $\$ \S 141-88$ (1952), did not, except in a few specified instances, clothe the federal courts with any power to deal with unfair labor practices. The court also made it clear that the Labor Management Relations Act of 1947 did not, except in a few specified instances, free the federal courts from the strictures of the Norris-LaGuardia Act, and that the federal court could not in any event enjoin the challenged conduct except as permitted by the Norris-LaGuardia Act. An assumption underlying the opinion is that the Norris-LaGuardia Act is applicable to all cases growing out of a labor dispute, irrespective of whether the defendant is a union or an employer. And $\$ 10(\mathrm{~h})$ and $10(\mathrm{j})$ of the Labor Management Relations Act, 49 STAT. 455 (1935), 61 SтAт. 149 (1947), 29 U.S.C. $\$ \$ 160(\mathrm{~h}), 160(\mathrm{j})$ (1952), support this assumption. The latter empowers the National Labor Relations Board to petition for an injunction after it has issued a complaint charging an unfair labor practice against either a union or an employer, and the former frees the courts from the limitations of the Norris-LaGuardia Act in disposing of such petitions. Section 208 of the Labor Management Relations Act, 61 STAT. 155 (1947), 29 U.S.C. $\$ 178$ (1952), affords similar support. This section empowers the federal courts to issue injunctions in certain cases involving strikes or lockouts imperiling the national health and safety, and it states that the Norris-LaGuardia Act shall not be applicable. Implicit in these provisions of the Labor Management Relations Act is the proposition that the Norris-LaGuardia Act is, in the absence of specific statutory provisions to the contrary, applicable to any case growing out of a labor dispute, irrespective of whether employer or employee conduet is in question.

Moreover, the same conclusion has been reached in actions brought against employers under $\$ 301$ (a). In United Packing House Workers v. Wilson \& Co., 80 F. Supp. 563 (N.D. Ill. 1948), the court adopted the reasoning of Amazon Cotton Mill Co. v. Textile Workers Union, supra, and stated:

"Wholly aside from the fact that Sec. 301(a) and (b) of the Labor Management

Relations Act of 1947 does not confer jurisdiction upon the Federal District Court to grant injunctive relief on petition of private parties ...., the Norris-LaGuardia Act deprives this court of jurisdiction to grant the injunction prayed for."

United Packing House Workers v. Wilson \& Co., stupra at 569. The court then stated that a controversy over compliance with a labor agreement is a labor dispute as defined by the Norris-LaGuardia Act, and pointed out the failure of the plaintiff union to allege compliance with $\S \S 7$ and 8 defeated its prayer for injunctive relief.

See also ILWU v. Libby, McNeill \& Libby, 114 F. Supp. 249 , motion for nety trial denied, 115 F. Supp. 123 (D. Hawaii 1953); Textile Workers Union v. Berryton Mills, 20 CCH LAB. CAs. II 66,519 (N.D. Ga. 1951); Local 937, UAW-CIO v. Royal Typewriter Co., 88 F. Supp. 669, 669-70 (D. Conn. 1949).

There are, however, several cases holding the Norris-LaGuardia Act inapplicable where the plaintiff seeks an order enforcing an agreement against an employer. Mill Drivers Union v. Gillespie Milk Products Corp., 203 F.2d 650 (6th Cir. 1953); Local 207, United Elec. Workers v. Landers, Frary \& Clark, 119 F. Supp. 877 (D. Conn. 1954); Textile Workers 
injunction is usually not available as a remedy for breach of a labor agreement, since Section $7^{60}$ requires proof of facts which do not ordinarily exist-e.g., fraud or violence.

Of the other promises contained in the agreement perhaps the most important is the promise to submit disputes to arbitration. The cases are in conflict on the question of the specific enforceability of such agreements, but a majority of the courts facing the question have denied relief. Of the minority, a few federal courts have interpreted Section 3or itself as authorizing specific enforcement of arbitration clauses in collective agreements, ${ }^{61}$ while the remainder have found their authority in the United States Arbitration Act. ${ }^{\text {e2 }}$

Taken alone, Section 4 of that statute appears to authorize such enforcement. Section $3^{63}$ sets forth a corollary rule which provides for issuance of a stay pending arbitration in any suit or proceeding brought in the courts of the United States upon an issue arbitrable under the agreement. And Section 2 of the statute specifies that written arbitration agreements "in any maritime transaction or ... contract evidencing a transaction involving commerce" are valid, irrevocable and enforceable. ${ }^{64}$

Section I, however, which defines the terms of Section 2, provides that "nothing herein contained shall apply to contracts of employment of seamen, railroad employees, or any other class of workers engaged in foreign or interstate commerce." ${ }^{165}$ [Emphasis added.] And the prevailing view is that the exclusion of Section I operates as to the entire statute, including Sections 3 and $4{ }^{68}$ Thus,

Union v. American Thread Co., 113 F. Supp. 137 (D. Mass. 1953); Textile Workers Union v. Aleo Mfg. Co., 94 F. Supp. 626 (M.D.N.C. 1950); Mountain States Div. No. 17, Communications Workers v. Mountain States Tel. \& Tel. Co., 81 F. Supp. 397 (D. Colo. 1948). 60. 47 Stat. 71 (1932), 29 U.S.C. $\$ 107$ (1952).

61. The Evening Star Newspaper Co. v. Columbia Typographical Union No. 101, 124 F. Supp. 322 (D.D.C. 1954); Local 207, United Elec. Workers v. Landers, Frary \& Clark, 119 F. Supp. 877 (D. Conn. 1954); Textile Workers Union v. American Thread Co., 113 F. Supp. 137 (D. Mass. 1953); Textile Workers Union v. Aleo Mfg. Co., 94 F. Supp. 626 (M.D.N.C. 1950). See also Milk Drivers Union v. Gillespie Milk Products Corp., 203 F.2d 650 (6th Cir. 1953). Contra: Local 205, United Elec. Workers v. General Elec. Co., 129 F. Supp. 665 (D. Mass. 1955). See also W. L. Mead, Inc. v. Teamsters Union, 217 F.2d 6 (1st Cir. 1954).

62. 9 U.S.C. $\$ 51-14$ (1952).

63. 9 U.S.C. $\$ 3(1952)$.

64. 9 U.S.C. $\$ 2(1952)$.

65. 9 U.S.C. $\$ 1$ (1952)

66. United Elec. Workers v. Miller Metal Products, Inc., 215 F.2d 221 (4th Cir. 1954); Pennsylvania Greyhound Lines, Inc. v. Amalgamated Ass'n of Street Employces, 193 F.2d 327 (3d Cir. 1952); Amalgamated Ass'n of Street Employees v. Pennsylvania Greyhound Lines, Inc., 192 F.2d 310 (3d Cir. 1951); United Furniture Workers v. Colonial Hardwood Flooring Co., 168 F.2d 33 (4th Cir. 1948); Gatliff Coal Co. v. Cox, 142 F.2d 876 (6th Cir. 
applicability of the Arbitration Act to collective agreements turns upon the construction of the phrase "contracts of employment." There is disagreement as to whether a collective agreement is a contract of employment. But the weight of authority holds that it is, and therefore that the Arbitration Act is inapplicable to collective bargaining agreements. ${ }^{67}$ Since the remedies of the statute are not available, the courts holding to this majority position follow the familiar common-law rule ${ }^{\text {es }}$ that executory promises to arbitrate are revocable at any time before issuance of the arbitral award. ${ }^{69}$ Thus neither a stay nor specific enforcement may be had.

The recent decision of the Third Circuit in Tenney Engineering, Inc. v. United Elec. Workers, ${ }^{70}$ that only the employment contracts of transport workers are excluded from the statute by the language of Section $I^{71}$ revives the possibility that the United States Arbitration Act may provide a legal foundation for grievance arbitration. ${ }^{72}$ At the present writing, however, federal enforcement of arbitration promises contained in labor agreements remains doubtful. ${ }^{73}$

1944); Commercial Packing Co. v. Butchers Union, 35 L.R.R.M. 2142 (S.D. Cal. 1954); Borg-Warner Corp. v. United Farm Equipment Workers, 34 L.R.R.M. 2174 (N.D. III. 1954); Ludlow Mfg. \& Sales Co. v. Textile Workers Union, 108 F. Supp. 45 (D. Del. 1952); Boston \& Me. Transp. Co. v. Amalgamated Ass'n of Street Employees, 106 F. Supp. 334 (D. Mass. 1952). Dictum, Lewittes \& Sons v. United Furniture Workers, 95 F. Supp. 851 , 855 (S.D.N.Y. 1951). But see Brady Transfer \& Storage Co. v. Local 710, Meat Drivers \& Helpers, 30 L.R.R.M. 2535 (N.D. Ill. 1952), and UOPWA v. Monumental Life Ins. Co., 88 F. Supp. 602 (E.D. Pa. 1950), in which the courts refused to rule on the point.

67. United Elec. Workers v. Miller Metal Products, Inc., 215 F.2d 221 (4th Cir. 1954); Pennsylvania Greyhound Lines, Inc. v. Amalgamated Ass'n of Street Employees, 193 F.2d 327 (3d Cir. 1952); Amalgamated Ass'n of Street Employees v. Pennsylvania Greyhound Lines, Inc., 192 F.2d 310 (3d Cir. 1951); United Furniture Workers v. Colonial Hardwood Flooring Co., 168 F.2d 33 (4th Cir. 1948); Gatliff Coal Co. v. Cox, 142 F.2d 876 (6th Cir. 1944); Borg-Warner Corp. v. United Farm Equipment Workers, 34 L.R.R.M. 2174 (N.D. Ill. 1954); Ludlow Mfg. \& Sales Co. v. Textile Workers Union, 108 F. Supp. 45 (D. Del. 1952); Boston \& Me. Transp. Co. v. Amalgamated Ass'n of Street Employees, 106 F. Supp. 334 (D. Mass. 1952). Contra: Brady Transfer \& Storage Co. v. Local 710, Meat Drivers \& Helpers, 30 L.R.R.M. 2535 (N.D. Ml. 1952); Lewittes \& Sons v. United Furniture Workers, 95 F. Supp. 851 (S.D.N.Y. 1951); UOPWA v. Monumental Life Ins. Co., 88 F. Supp. 602 (E.D. Pa. 1950).

68. Restatement, Contracts $\$ 550$ (1932); 6 Whliston, Contracts $\$ 1919$ (Iev. ed. 1938).

69. E.g., Utility Workers Union v. Ohio Power Co., 77 N.E.2d 629 (Ohio C.P. 1947).

70. 207 F.2d 450 (3d Cir. 1953).

71. In accord with the Tenney case is Harris Hub Bed \& Spring Co. Y. United Elec. Workers, 121 F. Supp. 40 (M.D. Pa. 1954). In United Elec. Workers v. Miller Metal Products, Inc., 215 F.2d 221 (4th Cir. 1954), the decision was contra.

72. The case is thoroughly discussed in Cox, Grievance Arbitration in the Federal Courts, 67 Harv. L. Rev. 591 (1954).

73. Collective bargaining agreements are a proper subject for invocation of the Federal Declaratory Judgments Act. Oil Workers Union v. Texoma Natural Gas Co., 146 F.2d 62 (5th Cir.), cert. denied, 324 U.S. 872 (1944); Northland Greyhound Lines, Ine. マ. Amalgamated Ass'n of Street Employees, 66 F. Supp. 431 (D. Minn.), appeal dismissed on dismissal of appeal by appellant, 157 F.2d 329 (8th Cir. 1946). And such judgments are 
What, then, of a plaintiff who seeks relief for breach of a labor agreement in a state court in order to avoid precedents restricting the availability of equitable remedies in the federal courts? Can the state court give him a remedy withheld by the federal forum?

The cases which hold that state regulation paralleling the Labor Management Relations Act is improper, ${ }^{74}$ might be thought to suggest a negative answer. The Supreme Court has shown tolerance for supplemental state remedies where they are compensatory in nature ${ }^{70}$ but the cases indicate an aversion to state preventive remedies. ${ }^{78}$ Such decisions are not apposite, however, because they involve either state intrusion upon the exclusive jurisdiction of the NLRB, a situation clearly not involved here, ${ }^{77}$ or state restraint of conduct protected by federal law. Section 7 of the LMRA ${ }^{78}$ guarantees rights to employees against state as well as employer interference. ${ }^{79}$ One of these is the right to engage in concerted activities for mutual aid or protection. However, a strike in breach of a collective bargaining agreement, while concerted activity in fact, is not the type of conduct protected by Section 7 of the Act. ${ }^{80}$ Furthermore, in the cases where state supplemental relief was not tolerated, the dificulty was that such relief conflicted so directly and positively with federal labor policy that the two could not be reconciled or consistently stand together. Such is not the case here. The NLRB has handed down a line of decisions recognizing the

available under $\$ 301$ (a). United Protective Workers v. Ford Motor Co., 194 F.2d 997 (7th Cír. 1952); AFL v. Western Union Tel. Co., 179 F.2d 535 (6th Cir. 1950); United Steel Workers v. Shakespeare Co., 84 F. Supp. 267 (W.D. Mich. 1949). But see ILWU v. Libby, McNeill \& Libby, 114 F. Supp. 249 (D. Hawaii), motion for new trial denied, 115 F. Supp. 123 (D. Hawaii 1953), in which declaratory judgment was denied because \$01(a) did not give the court jurisdiction.

74. E.g., Garner v. Teamsters Union, 346 U.S. 485 (1953); Amalgamated Ass'n of Street Employees v. Wisconsin Employment Relations Bd., 340 U.S. 383 (1951); UAW-CIO v. O'Brien, 339 U.S. 454 (1950); Plankinton Packing Co. v. Wisconsin Employment Relations Bd., 338 U.S. 953, reversing per curiam 225 Wis. 285, 38 N.W.2d 688 (1949); Ia Crosse Tel. Co. v. Wisconsin Employment Relations Bd., 336 U.S. 18 (1949).

75. See, e.g., United Constr. Workers v. Laburnam Constr. Corp., 347 U.S. 656 (1954).

76. See, e.g., Weber v. Anheuser-Busch, Inc., 348 U.S. 468 (1955); Garner v. Teamsters Union, 346 U.S. 485 (1953).

77. See p. 453 supra.

78. 61 Sтит. 140 (1947), 29 U.S.C. \$ 157 (1952).

79. See Hill v. Florida ex rel. Watson, 325 U.S. 538 (1945).

80. Joseph Dyson \& Sons, Inc., 72 N.L.R.B. 445 (1947); Scullin Steel Co., 65 N.L.R.B. 1294 (1946). See also United Elastic Corp., 84 N.L.R.B. 768 (1949) (an employer's statutory duty to bargain is suspended during the life of strike action in violation of a nostrike clause in the collective agreement); National Elec. Products Corp., 80 N.L.R.B. 995 (1948) (an employer will not be directed to reinstate employees who have suruck in breach of the agreement even though the employer's unfair labor practice provoked the strike). As to the latter case, see NLRB v. Thayer Co., 213 F.2d 748 (1st Cir.), cert. denied, 348 U.S. 883 (1954), in which the court said that the Board has the power to order reinstatement if reinstatement would effectuate the policies of the LARA. 
"traditional sanctity attached to contracts by our system of jurisprudence" by holding that employer conduct which would otherwise be an unfair labor practice is privileged where employees have struck in violation of the agreement. ${ }^{81}$ The Board has also undertaken to effectuate the statutory objective of stability in labor relations by holding that the parties may stand on their written bargain and refuse to negotiate over a particular issue, ${ }^{32}$ and that unilateral action is not a refusal to bargain when permitted by agreement. ${ }^{83}$ State enforcement of labor agreements by injunction, or by compelling specific performance, can hardly be said to work at crosspurposes with these policies. ${ }^{84}$

Moreover, the Norris-LaGuardia Act should not be read to preclude the states from giving equitable remedies in breach cases. That enactment is a jurisdictional statute which bears on federal judicial power, not on litigants' rights. ${ }^{85}$ Consequently it is diffcult to believe that the failure of Congress to remove the strictures of Norris-LaGuardia from actions brought to enforce a labor agreement in the federal courts manifested a policy that the injunction is an improper remedy when the federal right is asserted in a state court-to which the Norris-LaGuardia Act plainly does not apply. ${ }^{86}$

However, even though this reasoning is correct with respect to the effect of the LMRA and the Norris-LaGuardia Act, it does not necessarily follow that the state courts are free specifically to enforce a promise to arbitrate. In many conflict situations both federal and state courts have, with respect to provisions calling for arbitration, distinguished between remedial and primary rights in order to

81. See, e.g., United Elastic Corp., 84 N.L.R.B. 768, 773 (1949).

82. The Jacobs Mfg. Co., 94 N.L.R.B. 1214 (1951), enforcement granted, 196 F.2d 680 (2d Cir. 1952).

83. California Portland Cement Co., 101 N.L.R.B. 1436 (1952).

84. However, state enforcement of an executory promise to arbitrate does conflict with the NLRB rule that a union may refuse to arbitrate an issue in accordance with the established grievance procedure, and that the employer who insists upon resort to that procedure rather than bargaining at large commits the unfair labor practice of refusing to bargain. The Timken Roller Bearing Co., 70 N.L.R.B. 500 (1946). But this rule has not been warmly received by the courts of appeals. E.g., NLRB v. Standard Oil Co., 196 F.2d 892 (6th Cir. 1952), remanding The Standard Oil Co., 92 N.L.R.B. 227 (1950); Timken Roller Bearing Co. v. NLRB, 161 F.2d 949 (6th Cir. 1947), denying enforcement of The Timken Roller Bearing Co., 70 N.L.R.B. 500 (1946). The Board itself has shown some disposition to move away from the rule. Crown Zellerbach Corp., 95 N.L.R.B. 753 (1951) (complaint dismissed on theory that parties should resolve their disputes through grievance procedure rather than by resort to the NLRB).

85. 47 StaT. 70 (1932), as amended, 29 U.S.C. $\$ \$ 101-15$ (1952).

86. For a case in which a court so held, see General BIdg. Contractors' Ass'n v. Local Union No. 542, 370 Pa. 73, 87 A.2d 250 (1952). 
allow the forum to characterize the problem of enforcement as "procedural" and apply its own rules instead of those of another jurisdiction. ${ }^{\mathrm{s} 7}$ It is a substantive question whether an executory promise to arbitrate is valid, and the federal courts do hold that such a promise is valid. However, it is a remedial question whether a promise to arbitrate shall be enforced by a judgment for damages, an order directing arbitration or a stay, and thus the forum is entitled to apply its own rules. ${ }^{8 s}$

But the soundness of the distinction is doubtful, particularly when applied to suits in state courts under Section $301(\mathrm{a})$. The problem of whether the law of one jurisdiction must be followed by the other should be resolved, not by abstractions, but by looking at realities in the context of a specific problem. A substantive interpretation of the section would reflect a policy of uniformity irrespective of where the agreement is negotiated or performed, and within some limits, would necessitate uniformity of result irrespective of whether the forum is state or federal.$^{89}$ Federal substantive law applies in either forum. From the state court's point of view, therefore, the problem is the converse of that involved in Erie R.R.v. Tompkins. ${ }^{90}$ Accordingly, the Erie precedents would seem to have some bearing, and those precedents indicate that the courts will take a fairly realistic view in characterizing rules as substantive or procedural. ${ }^{11}$ Where its jurisdiction is based upon diversity, a federal court is foreclosed from granting relief if a state statute of limitations outlaws a claim ${ }^{32}$ or a state statute conditions

87. Red Cross Line v. Atlantic Fruit Co., 264 U.S. 109 (1924), is a leading case. See generally Gregory and Orlikoff, The Enforcement of Labor Arbitration Agreements, 17 U. of CHI. L. REv. 233 (1950); Phillips, Arbitration and Conflicts of Laws: $A$ Study of Benevolent Compulsion, 19 CoRNELI L.Q. 197 (1934).

88. E.g., Red Cross Line v. Atlantic Fruit Co., 264 U.S. 109 (1924).

89. See pp. 450-52 supra.

90. 304 U.S. 64, 114 A.L.R. 1487 (1938).

91. See, e.g., Guaranty Trust Co. v. York, 326 U.S. 99 (1945), in which the Supreme Court stated:

"「T he question is not whether a statute of limitations is deemed a matter of 'procedure' in some sense. The question is . . . does it significantly affect the result of a litigation for a federal court to disregard a law of a State that would be controlling in an action upon the same claim by the same parties in a State court?

"It is therefore immaterial whether statutes of limitation are characterized either as 'substantive' or 'procedural' in State court opinions in any use of those terms unrelated to the specific issue before us. . . . The nub of the policy that underlies Erie R. Co. v. Tomphins is that for the same transaction the accident of a suit by a nonresident litigant in a federal court instead of in a State court a block away should not lead to a substantially different result." Id. at 109.

92. E.g., Guaranty Trust Co. v. York, 326 U.S. 99 (1945). See also Ragan v. Merchants Transfer \& Warehouse Co., 337 U.S. 530 (1949) (federal court must follow state law requiring summons to be served within period of local statute). 
the right to relief upon filing a bond. ${ }^{93}$ These decisions may be thought not apposite to a rule denying specific enforcement because the plaintiff is theoretically able to obtain other forms of relief, e.g., damages, under such a rule. If, however, a rule denying all remedies must be followed because as a practical matter it renders the right meaningless, it would seem that a rule withdrawing the only effective remedy would also have to be followed. And damages are an ineffectual remedy for breach of a promise to arbitrate because measurable damages seldom, if ever, exist. ${ }^{\text {94 }}$ If, therefore, the federal courts may not, while sitting on a cause of action provided by a state, grant relief when the state has made the claim unenforceable in practical effect, it would be difficult to rationalize a different result in the converse situation where the federal government has made a claim unenforceable in its courts by withdrawing the only significant form of relief.

The argument can be made in still another way. The rule denying specific enforcement of an arbitration agreement leaves the promisor free to revoke the authority of the arbitrator to hear and decide the matter with binding effect. Thus, it is analogous to the common-law rule that a principal may revoke his agent's authority prospectively, thereby subjecting himself only to a damage action for breach. This substantive effect is clearly illustrated by the case in which the plaintiff sues on an arbitration award made pursuant to an arbitration agreement and the court finds that the defendant revoked prior to the making of the award. Under these circumstances it appears that state law denying enforcement will be followed by a federal court whose jurisdiction rests upon diversity. ${ }^{95}$ Conversely, a state court when jurisdiction is based upon Section 3 or should follow federal law.

Perhaps the argument would fail to carry the day simply because of the precedents which hold that the forum has power to determine the way in which a promise to arbitrate shall be enforced. However, it seems persuasive.

3. Removability. If we assume that the state courts do have jurisdiction to grant remedies not available in the federal courts, the question arises whether a state court action is removable. Since the cause of action is federal and is one over which the federal dis-

\footnotetext{
93. E.g., Cohen v. Beneficial Industrial Loan Corp., 337 U.S. 541 (1949).

94. See Restatement, Contracts $\$ 550$, comment a (1932).

95. See Tejas Development Co. v. McGough Bros., 165 F.2d 276, 278-79 (5th Cir.
} 1947). 
trict courts have original jurisdiction, the answer is plainly affirmative where the complaint is grounded on Section 301 (a).$^{96}$ Ordinarily, however, a plaintiff seeking relief in a state court will avoid mention of Section 301 (a) and ground its complaint on state law. The normal rule in removal proceedings prohibits the court from looking outside the complaint to determine whether or not a suit arises under federal law. ${ }^{97}$ Since Section 301 (a) pre-empts the field ${ }^{98}$ however, the question whether the federal district court would have had original jurisdiction hinges on the determination of the status of one of the parties-viz., a union representing employees in an industry affecting commerce. In such a case the court may ascertain the existence of that status independently of the complaint. ${ }^{99}$ Thus, the action would seem to be removable even when the complaint does not mention Section $301(\mathrm{a}) .^{100}$

It may be argued that the suit is not removable when the federal court lacks jurisdiction to grant the relief sought. Some courts have taken this position. ${ }^{101}$ Unless their approach prevails, moreover, the question whether the states have power to grant remedies not available in the federal courts will become largely academic, for the defendant in a breach action can be expected to exercise his right to remove in all cases where the federal courts lack power to grant the remedy sought.

4. Power to Refuse to Grant Remedies. As a practical matter, the question of the existence of a state's power to refuse to grant remedies available in the federal courts is not likely to arise. If an injunction or specific enforcement of an arbitration agreement is available in a federal court, a plaintiff seeking those remedies will hardly proceed in a state court where their availability is doubtful.

96. Sec 28 U.S.C. \$ 1441 (1952).

97. See Gully v. First Nat. Bank, 299 U.S. 109, 112-13 (1936).

98. See p. 452 supra.

99. Sec Direct Transit Lines v. Mackey, 34 L.R.R.M. 2572, 2576 (W.D. Mich. 1954); S. E. Overton Co. v. Teamsters Union, 115 F. Supp. 764, 768 (W.D. Mich. 1953); Pocahontas Terminal Corp. v. Portland Bldg. \& Constr. Trade Council, 93 F. Supp. 217, 219 (D. Me. 1950).

100. Fay v. American Cystoscope Makers, Inc., 98 F. Supp. 278, 280 (S.D.N.Y. 1951).

101. Associated Tel. Co. v. Communications Workers, 114 F. Supp. 334, 337 (S.D. Cal. 1953). For an analogous situation, see Castle \& Cooke Terminals, Ltd. v. Local 137, ILWU, 110 F. Supp. 247, 250-51 (D. Hawaii 1953). See also Hat Corp. v. United Hatters Union, 114 F. Supp. 890, 893 (D. Conn. 1953); American Optical Co. v. Andert, 108 F. Supp. 252, 254 (W.D. Mo. 1952). Contra: Direct Transit Lines v. Mackey, 34 L.R.R.M. 2572, 2580 (W.D. Mich. 1954). For analogous situations in which a view similar to that of Direct Transit Lines $v$. Mfackey was taken, see S. E. Overton Co. v. Teamsters Union, 115 F. Supp. 764, 772, 774 (W.D. Mich. 1953); Dircet Transit Lines, Inc. v. Local 406, Teamsters Union, 29 L.R.R.M. 2492, 2498, 30 L.R.R.M. 2471, 2476 (W.D. Mich.), petition for remand denied, 199 F.2d 89 (6th Cir. 1952); Pocahontas Terminal Corp. v. Portland Bldg. \& Constr. Trade Council, 93 F. Supp. 217, 219 (D. Me. 1950). 
However, the issue might be presented under the following circumstances. Suppose that the decisions holding that the United States Arbitration Act does not apply to collective bargaining agreements were overruled or superseded, and the federal courts would issue a stay pending arbitration in most suits brought under Section 301 (a) upon issues arbitrable under the agreement. If, in this state of affairs, an action was brought in a state court by a plaintiff who wished to litigate rather than arbitrate, the arbitration agreement being set up as a defense, the question would then present itself: May the state courts reject the defense, hear the case and decide it on its merits?

If the action was removable, which it generally would be, ${ }^{102}$ the question would be academic in most cases. If, however, the action was not removed, the question would be important. Despite the doctrine that the method of enforcement of an executory promise to arbitrate goes only to the remedy and is therefore a matter for the forum, it would seem that the state court should not decide the case on its merits. If the state court did disregard the promise to arbitrate, it would not be supplementing the remedial law of the federal courts. On the contrary, such action would be an attempt by the state to modify the remedial law of the federal courts. And in an analogous area such state action has been prohibited because it works at cross-purposes with federal law. ${ }^{103}$ To put the matter another way, the substantive basis for the commonlaw rule that a promise to arbitrate does not bar an action on the contract is the doctrine that the promise is independent of the other parts of the contract. ${ }^{104}$ By hypothesis, a federal court would issue a stay. Such action overcomes the common law and therefore has a "substantive" effect which the state courts must follow under a reverse Erie doctrine.

5. Power to Provide Supplemental Causes of Action. There are two requirements for an action brought under Section 301 (a). First, the claim must arise out of the violation of either an agreement between an employer and a union or an agreement between two unions. ${ }^{105}$ The latter type of agreement need not concern us

102. See pp. 462-63 supra.

103. See Union Fish Co. v. Erickson, 248 U.S. 308 (1919) (admiralty); dictum, Red Cross Line v. Atlantic Fruit Co., 264 U.S. 109, 124-25 (1924) (admiralty).

104. See Gatliff Coal Co. v. Cox, 142 F.2d 876, 881 (6th Cir. 1944).

105. E.g., R. O. Stenzel \& Co. v. Department Store Package Union, 11 F.R.D. 362 (W.D. Mo. 1951); Sun Shipbuilding \& Dry-Dock Co. v. Industrial Union of Marine Workers, 95 F. Supp. 50 (E.D. Pa. 1950); Snoots v. Vejlupek, 87 F. Supp. 503 (N.D. Ohio 1949); Kriss v. White, 87 F. Supp. 734 (N.D.N.Y. 1949). 
here. Second, the party asserting the claim must be either an employer or a union..$^{108}$ May a state provide a supplemental cause of action-one which is grounded on a collective bargaining agreement but is not cognizable under Section 301 ?

It would seem that the states could grant relief to an employee for the breach of a promise, for example, to pay wages. In the Westinghouse case, ${ }^{107}$ a majority of the Supreme Court Justices held that Section 301 does not give the federal courts jurisdiction to try actions brought by a union to enforce those terms of a collective bargaining agreement relating to compensation. The reasoning of the majority, as expressed in the opinions of the Chief Justice and of Mr. Justice Frankfurter, would seem broad enough to exclude from Section 30 r any actions brought by a union to enforce other provisions of the collective agreement that are "peculiar in the individual benefit which is their subject matter"10s - e.g., pensions, paid holidays and vacation benefits. But, as Mr. Justice Frankfurter noted, ${ }^{109}$ prior to the passage of Section $30 r$ the states were free to hold that individual employees have justiciable interests in such terms and to enforce them with appropriate remedies. There is no reason to suppose, even under a substantive interpretation of the section, that the states have lost this power since Section 3 or does not deal with such promises.

Indeed, this conclusion may even be reconciled with the view of the dissenting Justices in the Westinghouse case. Mr. Justice Douglas relied heavily on the Labor Management Relations Act, emphasizing that a union has standing under that statute to enforce all employer promises in the agreement, including those that accrue to individual employees. He argued that under federal law a union may be the suing as well as the bargaining agent, since grievance processing is part of collective bargaining as defined in the LMRA, and since a lawsuit is one way to settle a griev-

106. E.g., United Protective Workers v. Ford Motor Co., 194 F.2d 997 (7th Cir. 1952); Zaleski v. Local 401, United Elec. Workers, 91 F. Supp. 552 (D.N.J. 1950); dicta, Ketcher v. Sheet Metal Workers, 115 F. Supp. 802, 809 (E.D. Ark. 1953); Local 793, UAW-CIO v. Auto Specialties Mfg. Co., 15 F.R.D. 261, 264 (W.D. Mich. 1951); MacKay v. Loew's Inc., 84 F. Supp. 676, 677 (S.D. Cal. 1949), aff d, 182 F.2d 170 (9th Cir. 1950); Schatte v. IATSE, 84 F. Supp. 669, 673 (S.D. Cal. 1949), aff'd on other grounds, 182 F.2d 158 (9th Cir.), cert. denied, 340 U.S. 827 (1950).

107. Assaciation of Westinghouse Salaried Employees v. Westinghouse Elec. Corp., 348 U.S. 437 (1955).

108. Id. at 460. See II.WU v. Libby, McNeill \& Libby, 221 F.2d 225 (9th Cir. 1955) (action under $\$ 301$ by union against employer for back wages owed an employee allegedly discharged in violation of agreement dismissed on authority of the Westinghouse case).

109. Id. at 460 n.29. 
ance. ${ }^{110}$ But he did not say that the union is the exclusive suing agent. Mr. Justice Douglas' opinion may be read as meaning only that a union has a sufficient interest in the wage terms of the agreement to be entitled to whatever remedy is necessary to protect that interest. ${ }^{111}$ If so, the dissent's position is not inconsistent with the conclusion that the employees retain whatever causes of action they have under state law.

Moreover, this conclusion is supported by analogy to the situations under both the Railway Labor Act and Section 9(a) of the Labor Management Relations Act. The former recognizes that back wage claims are "accrued rights" which belong to the employees; $;^{\text {II2 }}$ the latter recognizes that employees may present their grievances directly to their employer. ${ }^{113}$

It also seems that the state may provide the union with a right of action to enforce the terms of the agreement relating to compensation. A dictum in Mr. Justice Frankfurter's opinion in the Westinghouse case supports the proposition that the union should have a right to sue to procure for individual employees the benefits promised in the agreement. ${ }^{114}$ Since the Court held that Section 301 does not grant jurisdiction over actions for compensation, the union will have a cause of action only if it is provided by the state. In fact, it would seem that the states will be free to provide the union with such a cause of action under a substantive or jurisdictional construction of the section. Since Section 9 (a) of the LMRA permits

110. Id. at $465-66$.

111. This was the position of the dissenting judges in the Third Circuit. Association of Westinghouse Salaried Employees v. Westinghouse Elec. Corp., 210 F.2d 623, 630-34 (3d Cir. 1954). In UAW-AFL v. Wilson Athletic Goods Mfg. Co., 119 F. Supp. 948 (N.D. Ill. 1950), the court held $\$ 301$ gives a union a right of action where the employer fails to grant certain employees paid vacations. See also AFL v. Western Union Tel. Co., 179 F.2d 535 (6th Cir. 1950) (jurisdiction of a union action for a declaratory judgment that a particular employee was entitled to a pension); Local 793, UAW-CIO v. Auto Specialties Mfg. Co., 15 F.R.D. 261 (W.D. Mich. 1951) (jurisdiction over union action to collect holiday pay for certain employees); Local 937, UAW-CIO v. Royal Typewriter Co., 88 F. Supp. 669 (D. Conn. 1949) (jurisdiction over union action to recover wages, brought on behalf of itself and a number of employees); United Shoe Workers v. Le Danne Footwear, Inc., 83 F. Supp. 714 (D. Mass. 1949) (jurisdiction over union action to recover damages for cmployer's failure to pay agreed wage scale).

112. Elgin, J. \& E. Ry. v. Burley, 325 U.S. 711 (1945), aff'd on rehearing, 327 U.S. 661 (1946).

113. 61 Srsr. 143 (1947), 29 U.S.C. $\$ 159$ (1952). For discussion, see Mr. Justice Frankfurter's opinion at 456-57, and Mr. Justice Douglas' dissent at 467 in Association of Westinghouse Salaried Employees v. Westinghouse Elec. Corp., 348 U.S. 437 (1955).

114. 348 U.S. 437, 457 (1955). One of the anomalies of the Westinghouse case is that five of the eight participating Justices (Frankfurter, Minton, Burton, Douglas and Black) agreed that the union had standing to bring the action. For purposes of comparison, see Textile Workers Union v. Textron, Inc., 111 A.2d 823 (N.H. 1955) (union may bring a bill in equity on behalf of the union members and in the name of its business agent for back wages allegedly due the former). 
the union to bring a grievance on behalf of an individual employee, ${ }^{115}$ a state-created cause of action is complementary to federal labor policy. It is possible that even Justices Douglas and Black would share this view, for the dissenting opinion does not indicate that the union can be the suing agent only when it brings an action under Section 301. ${ }^{116}$ However, since Section 301 pre-empts the field, it would seem that a state cause of action would here be precluded since it is the view of these Justices that the union has a cause of action under Section 30r. It is predictable that Mr. Justice Reed would deny the states the power to provide such a right of action to a union; he said that a union has no justiciable interest in wage claims under federal substantive law because the claims do not arise out of the agreement to which the union is a party. ${ }^{117}$

If we accept the view that the states may provide the union or individual employees with a right to enforce those provisions of the collective agreement that relate to compensation or similar individual benefits, does it follow that they may provide the union or the employees with enforceable rights which arise out of other terms of the collective agreement? Suppose, for example, that a collective agreement provides that no employee shall be discharged without good and sufficient cause. Section 301 authorizes a federal action by a union to enforce such a provision. ${ }^{118}$ The state cannot, therefore, provide the union with a cause of action since Section 30I, if substantive, pre-empts the field. ${ }^{119}$ Does the section also foreclose the states from providing the employees with a cause of action? Under Section 30r only the union can sue, and thus only the union has a justiciable interest under federal law in the enforcement of such a contract term. For the state to grant a cause of action to the individual employee might be thought to interfere with the paramount federally created right of the union, but the extent of interference would vary from case to case. It is one thing for the state to provide an employee with a cause of

115. See note 113 supra.

116. Association of Westinghouse Salaried Employees v. Westinghouse Elec. Corp., 348 U.S. 437,465 (1955).

117. Id. at 464. This position conforms to the theory that the wage terms of a collective bargaining agreement merely establish a custom and usage which becomes a part of an employee's contract of employment and may be enforced only by him. See Association of Westinghouse Salaried Employecs v. Westinghouse Elec. Corp., 210 F.2d 623 (3d Cir. 1954).

118. United Protective Workers v. Ford Motor Co., 194 F.2d 997 (7th Cir. 1952). But see ILWU v. Libby, McNeill \& Libby, 221 F.2d 225 (9th Cir. 1955).

119. See p. 452 supra. 
action where the controversy involves his discharge; it is quite a different thing where the dispute involves, for example, the checkoff of dues provision in the collective agreement. Thus, the problem would seem to require the federal courts to draw a line between those terms which give rights to both individual employees and the union and those that give rights only to the union. In the Westinghouse case Mr. Justice Frankfurter expressly rejected the proposition that Section 30r calls on the federal courts to work out a "viable theory of the nature of a collective bargaining agreement." ${ }^{\prime 20}$ But it should be remembered that the Justices whose views were represented in his opinion construed Section zor as merely jurisdictional, and in part it was the prospect of the federal courts' developing a theory as to the nature of a collective bargaining agreement that led them to give Section $30 \mathrm{r}$ a jurisdictional reading. If the Court gives Section 3or a substantive interpretation, it is difficult to see how the federal judiciary can avoid working out some "viable theory of the nature of a collective bargaining agreement."

The courts might, for example, take the position that under federal law only the union can enforce the provisions of the agreement that predominantly serve group interests. ${ }^{121}$ What power would then be left to the states to provide individual employees with a right of action? Suppose, for example, that a nonunion employee brought an action under state law for damages on the ground that he was discharged without good cause. The employer's defense is that the employee refused to carry out his foreman's order. The parties agree that the order was proper and that if the employee did in fact refuse to execute it, he was guilty of insubordination, which constitutes good cause for dismissal. The question raised is one of fact peculiar to the employee. It does not involve construction of the agreement and may be settled without conflict with the uniform federal substantive law governing the interpretation of such agreements. Hence, there would seem to be no reason

120. Association of Westinghouse Salaried Employees v. Westinghouse Elec. Corp., 348 U.S. 437, 456 (1955).

121. See MacKay v. Loew's Inc., 182 F.2d 170 (9th Cir. 1950), in which the coure held that a closed shop provision was not intended for the benefit of an individual employee and hence that he could not sue the employer for violation of the provision.

The European theory is that some terms of the collective bargaining agreement are contractual insofar as they impose conditions and obligations to be performed by the employer and the union and that they create rights and duties running between those two contracting parties only. This analysis of the nature of a collective agreement is set forth in Mathews, Labor Relations aNd the LAW 309-11 (1953). 
why a state court should not be permitted to entertain the employee's action. ${ }^{122}$ The same result would seem proper even though the employee also sought reinstatement and restoration of seniority rights although he might encounter other obstacles to relief. ${ }^{123}$ Such a remedy affects future relations betweeen the employer and other employees and possibly could not, therefore, be given by a state if the claim arose under an agreement subject to the Railway Labor Act. ${ }^{124}$ Underlying the cases arising under the Railway Labor Act, however, is the policy of protecting the jurisdiction of the Railway Adjustment Board, ${ }^{125}$ a policy not involved here.

Suppose further, however, that the employer presents a second defense in the litigation-viz., that claims arising under the collective bargaining agreement must, by the terms of the agreement, be submitted to the prescribed grievance procedure for settlement. The defense raises two issues: ( $\mathrm{I}$ ) Is the claim one "arising under" the agreement? (2) If it is, does the promise to exhaust the grievance procedure bind a nonunion employee? In any situation where a state gives a right of action to an employee who is claiming that an employer has violated a term of the collective agreement, it seems plain that the validity of the claim should be determined in a manner harmonious with federal law. Absent such a result, the rights and duties of the parties as defined by federal law might well conflict with their rights and duties as defined by

122. This result is supported by analogy to the Fifth Circuit's analysis, Hughes Tool Co. v. NLRB, 147 F.2d 69 (5th Cir. 1945), enforcing as modified Hughes Tool Co., 56 N.L.R.B. 981 (1944), of the Wagner Act version of $\$ 9(a)$ of the Taft-Hartley Act. The court distinguished between those employee claims which involve a question of the meaning and scope of the bargain and those that raise only an issue of fact or conduct peculiar to the employee and held that the employee has the right to present the latter to his employer without the intervention of the union. This employee "right" has presumably been broadened by the Taft-Hartley amendment to $\$ 9(a)$, although the union is entitled to notice and may challenge the settlement on the ground that it is inconsistent with the collective bargaining agreement.

123. In Misetta v. National Bronze \& Aluminum Foundry Co., 107 N.E.2d 243 (Ohio App. 1952), it was suggested that $\$ 301$ does not pre-empt either a class action or a suit by an individual employee for specific enforcement of those terms of the agreement relating to lay-offs brought on the theory that the employees are the third party beneficiaries of such terms. However, the decision permitting the action under state law was reversed in Masetta v. National Bronze \& Aluminum Foundry Co., 159 Ohio St. 306, 112 N.E.2d 15 (1953), in part on the ground that a collective bargaining agreement is a contract for personal services which a court of equity will not specifically enforce.

124. See Hippenstcel v. System Federation No. 9, 337 Mich. 251, 59 N.W.2d 278 (1953); Isgett v. Atlantic C.L.R.R., 223 S.C. 56, 74 S.E.2d 220 (1953).

On the other hand an employee may regard his discharge as severing his employment and sue under state law for damages on the ground that his discharge violated the agreement. Moore v. Illinois Cent. R.R., 312 U.S. 630 (1941); dictum, TWA v. Koppal, 345 U.S. 653, 660-61 (1953).

125. See Order of Ry. Conductors v. Southern Ry., 339 U.S. 255 (1950); Slocum v. Delaware, L. \& W.R.R., 339 U.S. 239 (1950). 
state law. ${ }^{126}$ Not only would such conflicts present opportunities for forum shopping, but they would also work against one of the principal reasons for enacting Section 3or-that the parties to collective agreements should be able to rely on their terms. But the policy of uniformity reflected by a substantive interpretation of Section zor may be carried out for one example by merely requiring the state to apply the federal rule governing both issues. ${ }^{127}$ This is so even if the union has also brought an action seeking to protect the group interest abridged by the same violation. Uniformity here does not require a holding that the state is without power to provide the employees with a cause of action based upon the alleged violation of the agreement. ${ }^{128}$

\section{THE IMPLICATIONS OF a JURISDICTIONAL INTERPRETATION}

In contrast to a substantive interpretation of Section 3or, adoption of the view that the section merely provides a federal forum for protection of the rights and duties acquired by the exercise of the power guaranteed employers and unions to enter into collective agreements would cause no serious inroads on the powers of the states. State law would operate very much as it does in diversity cases under the Erie doctrine. State power to fashion

126. See Shirley-Herman Co. v. International Hod Carriers, 182 F.2d 806, 808-9 (2d Cir. 1950).

127. While the proviso to $\$ 9$ (a) of the LMRA speaks of the employee's "right" to present his grievance to his employer and have it adjusted, the proviso probably creates only an exception to the employer's duty to bargain exclusively with the union. Thus, it is merely an employer privilege, one which may be waived by agreement. Where the agreement contains such a waiver and requires all grievances to be submitted through the union, the employee cannot sue on any claim under the agreement until he has exhausted the grievance procedure. See United Protective Workers v. Ford Motor Co., 194 F.2d 997, 1001-2 (7th Cir. 1952). The employee's remedy, if the union officials arbitrarily refuse to process his grievance, is to assert a cause of action grounded on the union's breach of its duty fairly to represent each employee in the bargaining unit. Ford Motor Co. v. Huffman, 345 U.S. 330 (1953) (by implication). See Note, Duty of Union to Minority Groups in the Bargaining Unit, 65 Harv. L. Rev. 490 (1952). See also Hughes Tool Co., 104 N.L.R.B. 318 (1953).

But see TWA v. Koppal, 345 U.S. 653 (1953), in which the Supreme Court held that a state may apply a local rule requiring exhaustion to an otherwise proper employee action for damages for wrongful discharge under a collective bargaining agreement subject to the Railway Labor Act. Apparently a state may also apply a local rule which does not require exhaustion, Moore v. Illinois Cent. R.R., 312 U.S. 630 (1941), although an employee who is asserting an "accrued right" under the agreement has standing before the Railway Adjustment Board unless he has authorized the union to act for him. Elgin, J. \& E. Ry. v. Burley, 325 U.S. 711, 738 (1945), affd on rehearing, 327 U.S. 661, 663-64 (1946).

128. In United Protective Workers v. Ford Motor Co., 194 F.2d 997 (7th Cir. 1952), the employee brought an action under state law for wages lost by virtue of an allegedly wrongful discharge. The federal court took jurisdiction over his cause because there was diversity of citizenship and permitted him to join the union, which was seeking a declaratory judgment under $\$ 301$ to the effect that the employee's discharge was a breach of the agreement, on the ground that the questions of law and fact were common to the employee and the union. 
rules governing the breach of collective bargaining agreements would remain unrestricted. The federal courts would follow those rules. ${ }^{120}$

There would be exceptions, however, where Congress has spoken. In that case federal law would control without reference to whether the issue would be characterized as substantive or procedural in the absence of such a declaration. ${ }^{130}$ Under any view of Section 3or, for example, service on a union officer gives a federal court jurisdiction over a suit against the union in its common name despite a state rule to the contrary. ${ }^{131}$ Similarly, issues governed by the LMRA, e.g., the capacity of the parties, should be disposed of by applying the federal rule.

Furthermore, it should be remembered that under a jurisdictional interpretation of Section 30I, federal jurisdiction does not rest on diversity, but rather on the "arising under" clause of Article III. Under these circumstances it would seem that the federal courts are freer to ignore state rules than they have been in diversity cases. Because of the control which Congress has over the availability of equitable remedies in the federal courts, the Erie doctrine does not restrict the power of the federal courts where uniform equity practice in those courts is necessary in order to implement a congressional command. Thus, the issue turns on a judgment as to

129. See, e.g., Mercury Oil Refining Co. v. Oil Workers, 187 F.2d 980 (10th Cir. 1951), in which the court held that $\S 301$ (a) only confers jurisdiction. The court said a federal court has no greater or different power than a state court would have had if the action had been brought there. See also Hamilton Foundry \& Mach. Co. v. International Molder \& Foundry Workers Union, 193 F.2d 209 (6th Cir. 1951), cert. denied, 343 U.S. 966 (1952), where the Sixth Circuit affirmed the dismissal of a suit brought under $\$ 301$ on the ground that an oral contract was invalid under the Ohio Statute of Frauds.

"Although the contract and federal jurisdiction to enforce it arise out of a federal statute, the enforcement of the right must conform to the remedy prescribed by the law of the state where the action is brought. We agree with appellant that a state statute cannot change or diminish a substantive right created by a federal statute ... but a state statute is applicable where it deals with the remedy rather than with the substantive right."

Id. at 215 .

If $\S 301$ is substantive, the result-not the reasoning-may be proper by analogy to those eases where the federal court adopts a state statute of limitations where the federal statute is silent. But see Rabouin v. NLRB, 195 F.2d 906 (2d Cir. 1952), in which the court held that a state statute of frauds could not transform into an unfair labor practice activity under the LMRA otherwise validated by a binding oral contract between employer and union. See also Cope v. Anderson, 331 U.S. 461 (1947); Campbell v. City of Haverhill, 155 U.S. 610 (1895).

130. See Herget v. Central Nat. Bank \& Trust Co., 324 U.S. 4 (1945).

131. Isbrandtsen Co. v. National Marine Engineers' Beneficial Ass'n, 9 F.R.D. 541 (S.D.N.Y. 1949).

In diversity actions the rule of the state in which the federal court sits governs the question of whether a union has capacity to sue or to be sued in its common name. International Allied Printing Trades Ass'n v. Master Printers Union, 34 F. Supp. 178 (D.N.J. 1940). 
the nature of the command. It would seem that the federal courts are free to determine that Section 301 commands uniform effective enforcement by the application of federal equitable remedies. Thus, even under a jurisdictional interpretation of Section 3 or a federal court might, for example, grant specific performance of an arbitration agreement without regard to the state rule on the matter. ${ }^{132}$ Presumably, however, the states would remain free to apply their own remedies when suit was brought in a state court. ${ }^{133}$

\section{WHICH CHOICE?}

\section{A. Language and Legislative History of Section 301}

Having examined the far-reaching impact upon existing state power which would result from a substantive as contrasted with a jurisdictional construction of Section 3or, we are now in a better position to evaluate which of the two interpretations should be adopted. It would appear that the sweeping impact of a substantive construction should in itself restrain the Court from concluding that Section $30 \mathrm{I}$ is other than jurisdictional in the absence of a relatively clear congressional mandate that Section 3 or is substantive. Certainly, it is for Congress in the first instance to make labor policy restricting so materially the traditional powers of the states. ${ }^{134}$ Has Congress done so?

To say that the required congressional mandate is lacking greatly understates the case, for the language and legislative history of Section 301 affirmatively suggest that Congress intended to provide unions and employers with a federal forum and nothing more. In the first place, the legislative managers of the bills which subsequently became the Taft-Hartley Act were primarily con-

132. See Textile Workers v. American Thread Co., 113 F. Supp. 137 (D. Mass. 1953).

133. If the plaintifi sues in a state forum, is the action removable in the absence of diversity? Even though state substantive law would have been applicable if the suit had been initiated in a federal court, the court's jurisdiction would have been based ultimately upon the "arising under" clause of the Constitution. The general removal statute, 28 U.S.C. $\$ 1441$ (1952), provides:

"Any civil action of which the district courts have original jurisdiction founded on a claim or right arising under the Constitution, treaties or laws of the United States shall be removable without regard to the citizenship or residence of the parties." This general jurisdictional statute probably does not extend to the district courts all of the "arising under" jurisdiction with which Congress has the constitutional power to invest the federal judiciary. See p. 477 infra; Association of Westinghouse Salaried Employees v. Westinghouse Elec. Corp., 348 U.S. 437, 450 (1955). A jurisdictional reading of $\$ 301$, on the other hand, strains this power to the limit. See pp. 477-78 infra.

134. Such was the view of Mr. Justice Frankfurter in the Westinghouse case. Association of Westinghouse Salaried Employees v. Westinghouse Elec. Corp., 348 U.S. 437 453-54 (1955). 
cerned with making such agreements bilaterally enforceable by removing the procedural obstacles to effective legal action against unions. ${ }^{136}$ Second, the language of Section 301 (a) merely provides that suit may be brought in a federal district court. It makes no reference to federal substantive law. Moreover, the other four subsections plainly deal with matters of procedure. Subsection (b) provides that unions may sue or be sued as entities, with money judgments enforceable only against the entity and its assets, while subsections (c) and (d) set forth rules in respect to venue and the service of process. ${ }^{136}$ Subsection (b) also states that unions and employers are bound by the acts of their agents. This provision might appear to be substantive, but if read in conjunction with subsection (e), which states that in "determining whether or not a person is an 'agent,' the question of whether the specific acts were actually authorized or subsequently ratified shall not be controlling," it appears to mean only that the federal courts may operate free of the strictures of Section 6 of the Norris-LaGuardia $\mathrm{Act}^{137}$ in deciding issues of vicarious liability. Neither subsection (b) nor (e) contains a statutory command as to the applicable substantive law of agency. Accordingly, the background and the language of the section lead to the conclusion that Section $30 \mathrm{I}$ merely provides a forum in which actions for breach may conven-

135. See H.R. REP. No. 245, 80th Cong., 1st Sess. 6, 46 (1947); Cox, Some Aspects of the Labor Management Relations Act, 1947, 61 Harv. L. REv. 274, 304 (1948). See also the opinion of Mr. Justice Frankfurter in Association of Westinghouse Salaried Employees v. Westinghouse Elec. Corp., 348 U.S. 437, 441-49 (1955).

There is, however, some slight evidence that Congress intended to create a federal substantive right.

"There are no Federal laws giving either an employer or even the Government itself any right of action against a union for any breach of contract. Thus there is no 'substantive right' to enforce, in order to make the union suable as such in Federal courts."

SeN. Rep. No. 105, 80th Cong., 1st Sess. 17 (1947). Apparently the sentence quoted is a reference to Rule 17 (b) of the Federal Rules of Civil Procedure, which provides that an unincorporated association may sue or be sued in its common name for the purpose of enforcing for or against it a substantive right existing under the Constitution or laws of the United States. FED. R. Crv. P. 17(b).

136. Section 301(c) gives the federal courts jurisdiction over a union which either has its principal office or acts for cmployee members within the district. See Daily Review Corp. v. International Typographical Union, 9 F.R.D. 295 (E.D.N.Y. 1949). Section 301 (d) specifies that service of legal process on a union agent is service on the union. See Clayeraft Co. v. United Mine Workers, 204 F.2d 600 (6th Cir. 1953) (service upon regional director of district of a national union is service upon the national union); Isbrandtsen Co. v. National Marine Engincers' Beneficial Ass'n, 9 F.R.D. 541 (S.D.N.Y. 1949) (local union is not an agent of an international union; service on the former is not service on the latter).

137. Conf. REP. No. 510, 80th Cong., 1st Sess. 66 (1947); United Mine Workers v. Patton, 211 F.2d 742 (4th Cir.), cert. denied, 348 U.S. 824 (1954). 
iently be brought by parties who might otherwise be hamstrung by procedural obstacles if only a state forum were available. ${ }^{\text {ss }}$

The only cross-reference in the statute is consistent with this interpretation. Section 303(a) makes certain labor union conduct unlawful, and Section 303(b) states:

Whoever shall be injured in his business or property by reason or [sic] any violation of subsection (a) of this section may sue therefor in any district court of the United States subject to the limitations and provisions of Section 3or hereof without respect to the amount in controversy, or in any other court having jurisdiction of the parties, and shall recover the damages by him sustained. . . . ${ }^{138}$

Obviously, the reference to Section 3 or embraces only subsections (b), (c), (d) and (e), and a fair reading is that both Sections $301(a)$ and 303 (b) confer jurisdiction, with subsections (b), (c), (d) and (e) of Section $30 x$ applicable to actions brought under either. ${ }^{140}$

While this analysis sheds no light on the meaning of $30 x(a)$, a comparison of the two sections does. Section 303(b) clearly provides for the enforcement of federal substantive rights and expressly confers jurisdiction on the state courts. While it is silent as to federal court jurisdiction over non-diversity cases, such jurisdiction is normally inferred where a federal right is being enforced. ${ }^{141}$ Section 301 (a) on the other hand expressly confers jurisdiction over non-diversity cases upon federal courts but is silent in respect to state court jurisdiction. Why the difference

138. The existence of a federal forum for breach of a collective bargaining agreement, apart from $\$ 301$, is limited. Where diversity of citizenship exists, the capacity of the union to sue or be sued is determined by the law of the state where the federal court is located. Pullman Standard Car Mfg. Co. v. Local Union No. 2928, 152 F.2d 493 (7th Cir. 1945). However, an unincorporated association has no citizenship even in a state where it may sue or be sued in its common name. Its citizenship is determined by that of its members, and the citizenship of each member must be diverse from that of the other party. Hettenbaugh v. Airline Pilots Ass'n Int'l, 189 F.2d 319 (5th Cir. 1951); Stein v. Brotherhood of Painters, 11 F.R.D. 153 (D.N.J. 1950); Sun Shipbuilding \& Dry-Dock Co. v. Industrial Union of Marine \& Shipbuilding Workers, 95 F. Supp. 50 (E.D. Pa. 1950); International Allied Printing Trades Ass'n v. Master Printers Union, 34 F. Supp. 178 (D.N.J. 1940). This obstacle, however, can be overcome by bringing a class action and carefully selecting the representatives, for only the diverse citizenship of the representatives need appear.

139. 61 STAT. 159 (1947), 29 U.S.C. \$187(b) (1952).

140. See Schatte v. IATSE, 84 F. Supp. 669 (S.D. Cal. 1949), affd, 182 F.2d 158 (9th Cir.), cert. denied, 340 U.S. 827 (1950); Lach v. Hoisting \& Portable Power Shovel \& Dredge Engineers, 86 F. Supp. 463 (D. Mass. 1949).

141. See Schatte v. IATSE, 182 F.2d 158, 165 (9th Cir.), cert. denied, 340 U.S. 827 (1950); Pepper \& Potter, Inc. v. Local 977, UAW-CIO, 103 F. Supp. 684, 689-90 (S.D.N.Y. 1952); Banner Mfg. Co. v. United Furniture Workers, 90 F. Supp. 723, 724 (S.D.N.Y. 1950). But see Lach v. Hoisting \& Portable Power Shovel \& Dredge Engineers, 86 F. Supp. 463,464 (D. Mass. 1949). 
between these two sections? Many explanations may be advanced, but the most obvious one is that Section $301(a)$, unlike Section 303(b), was intended only to open the federal courts to litigants who would otherwise not be able to get there.

\section{B. Constitutionality}

But such an interpretation raises a constitutional question: Did Congress have the power to make the federal court an available forum without at the same time commanding that the litigants' rights shall be determined by federal substantive law? The question is one that the Court has not yet decided.

A negative answer would rely upon the fact that Congress could only have grounded jurisdiction under Section 301 upon the "arising under" clause of Article III of the Constitution since Section 301 (a) grants jurisdiction irrespective of diversity. But Congress allowed state law to govern the plaintiff's claim. Congress, it would be argued, had no power to do both of these things, because

[a] lmost without exception, decisions under the general statutory grants of jurisdiction strikingly similar to the constitutional wording, have tested jurisdiction in terms of the presence, as an integral part of plaintiff's cause of action, of an issue calling for interpretation or application of federal law. ${ }^{142}$

There are two possible answers to this constitutional objection. One is that jurisdiction need not be grounded on Article III. The other is that the "arising under" clause in Article III is not limited to issues calling for interpretation or application of federal law.

The first answer is suggested by National Mut. Ins. Co.v. Tidewater Transfer $\mathrm{Co}^{143}$ In that case, Mr. Justice Jackson, in an opinion joined by two other Justices, ${ }^{144}$ argued that Congress could give jurisdiction to the federal courts to hear cases between the citizens of the District of Columbia and citizens of a state-even though the cause of action was granted by the state, the law applied was state law, and the District of Columbia was not a state within the meaning of the diversity clause of Article III. Mr. Justice

142. Association of Westinghouse Salaried Employees v. Westinghouse Elec. Corp., 348 U.S. 437, 450 (1955). See note 9 supra.

143. 337 U.S. 582 (1949).

144. Justices Black and Burton joined in the Jackson opinion. Id. at 583. Justices Rutledge and Murphy concurred in the result but not in the reasoning. Id. at 604. The remainder of the Court dissented from both the reasoning and the result. Id. at 626, 646 . 
Jackson maintained that Congress could provide a judicial forum for District citizens in any Article III court since Congress is empowered by Article I "to exercise exclusive Legislation" over the District, ${ }^{145}$ and that these courts derived their constitutional authority from Article I when hearing cases between citizens of the District and citizens of another state.

To the extent that Mr. Justice Jackson was correct in his assumption that any court created under Article III may handle Article I business, it is immaterial to the constitutionality of Section 3 or whether it satisfies the technical requirements of the "arising under" clause. Inasmuch as Article I also authorizes Congress to legislate with respect to interstate commerce, ${ }^{146}$ it seems to follow from the Jackson position that the district courts could be empowered through the Commerce Clause to adjudicate by state law the rights and duties created by a collective bargaining agreement between an employer and a labor organization representing employees in an industry affecting commerce. If such an analysis is accepted, the only constitutional issue is whether Congress has transcended the scope of the Commerce Clause. That question is answered in the negative by those cases holding that Congress has created a constitutionally valid federal substantive law by enacting Section 30r. ${ }^{147}$ Certainly, absent any Article III problem, Congress can provide a federal forum if it can provide a federal substantive law plus a forum.

The difficulty with this line of reasoning lies in the fundamental proposition that courts established under Article III may be given jurisdiction by virtue of the power granted Congress in Article I, even though such jurisdiction does not satisfy the requirements of Article III. The majority of the Justices in the Tidewater case were of the opinion, for either historical or administrative reasons, that this was not the case. ${ }^{148}$ And their analysis, particularly that of Mr. Justice Frankfurter, ${ }^{149}$ seems persuasive.

The outlines of a second possible answer to the suggestion that Section 30 is unconstitutional are supplied by Mr. Justice Frankfurter's opinion in the Westinghouse case, ${ }^{150}$ although the

145. U.S. CoNsT. Art. I, $\$ 8$.

146. Ibid. 1950).

147. E.g., Shirley-Herman Co. v. International Hod Carriers, 182 F.2d 806 (2d Cir.

148. National Mut. Ins. Co. v. Tidewater Transfer Co., 337 U.S. 582 (1949).

149. Id. at 646 .

150. Association of Westinghouse Salaried Employees v. Westinghouse Elec. Corp., 348 U.S. $437,450-52$ (1955). 
opinion, quite properly in light of the disposition of the case, leaves the validity of this answer very much in doubt.

This approach assumes that the general statutory grant of jurisdiction to the federal courts did not exhaust the constitutional grant of jurisdiction even though the statutory grant contains language very similar to the language of Article III. Most writers who have examined the question have concluded that this assumption is correct. ${ }^{151}$ Therefore, the decisions holding that there is no federal jurisdiction question unless an integral part of the plaintiff's claim requires the application or construction of federal law ${ }^{162}$-that is, that some aspect of federal law must be essential to his success-are not apposite. They are only authority on the dimensions of the statutory grant of jurisdiction, not on the dimensions of congressional power.

On such a premise it could be argued that Congress has the power to open federal courts for the enforcement of a state cause of action in order to protect its federal labor program. In his dissent in the Tidewater case, Mr. Justice Frankfurter stated:

Courts set up under Article III to exercise the judicial power of the United States do so either because of the nature of the subject-matter or because of the special position of the parties. So far as the subject-matter is concerned, it extends to cases arising under the 'Constitution, the Laws of the United States, and Treaties,' . . . Article I, $\S 8$, is an enumeration of the subjects in relation to which the Constitution authorizes Congress to make laws. Its eighteen divisions of legislative power are the sources of federal rights and sanctions. Laws enacted under them are 'the Laws of the United States,' to which the 'judicial porver,' granted by Article III, extends. Laws affecting revenue, war, commerce, immigration, naturalization, bankruptcy, and the rest ... are the generating sources of 'all Cases, in Law and Equity, arising under . . . the Laws of the United States,' and therefore cognizable by the courts established under Article III. Congress can authorize the making of contracts; it can therefore authorize suit thereon in any district court. Congress can establish post offices; it can therefore authorize suits against the United States for the negligent killing of a child by a post-office truck. ${ }^{163}$

Congress has authorized a federal labor policy based upon collective bargaining, ${ }^{154}$ is it not permissible for Congress to authorize

151. See, e.g., Mishkin, The Federal "Question" in the District Courts, 53 Cor. I. REv. 157, 160 (1953); Shulman and Jaegerman, Some Jurisdictional Limitations on Federal Procedure, 45 YALE L.J. 393, 405 n.47 (1936); Wechsler, Federal Jurisdiction and the Revision of the Judicial Code, 13 Law \& Conterrp. Pros. 216, 225 (1948).

152. See note 10 supra.

153. National Mut. Ins. Co. v. Tidewater Transfer Co., 337 U.S. 582, 649 (1949).

154. 49 Star. 449 (1935), as amended, 61 STAT. 136 (1947), 29 U.S.C. $\$ 151$ (1952). 
suits for breach of agreements which are the product of that bargaining?

It would seem that the relation of Section 301 to the federal program is in itself enough to characterize the jurisdictional grant in Section $30 x$ as arising under the Laws of the United States. ${ }^{155}$ Put another way, Congress in this section has established a "protective" jurisdiction. ${ }^{156}$ Even though in any given suit a federal substantive issue may be remote, Congress has deemed it necessary to provide a federal forum for the adjudication of disputes arising out of collective agreements between parties whose rights and duties in the negotiation of the agreement are in large measure controlled by federal legislation, ${ }^{157}$ and whose conduct vis-a-vis each other during the term of the agreement is in substantial part controlled by this same legislation. ${ }^{108}$ A federal forum is necessary to protect the federal labor program because of the procedural difficulties of suing a union in a state court. ${ }^{159}$ It is clear that Congress had the power to provide a substantive law governing rights under labor agreements. ${ }^{160}$ It has chosen instead to permit state law to operate in this area of labor-management relations, provided the federal courts constitute an available forum for the enforcement of these state rights. State law fills the gap in the federal labor program. The federal courts provide the judicial forum in which these state rights are tested. Such a forum is essential to protect the over-all scheme Congress has devised to facilitate the free flow of interstate commerce. ${ }^{161}$

155. See Cox, Some Aspects of the Labor Management Relations Act, 1947, 61 Harv. L. REv. 274, 304 (1948).

156. This phraseology is suggested by Hart and Wechszer, The Federal Counts AND THE FEDERAL SysteM 744-47 (1953), and Mishkin, The Federal "Question" in the District Courts, 53 Cor. L. Rev. 157, 184-96 (1953).

157. See 61 STAT. 141 (1947), 29 U.S.C. $\$ \$ 158(a)(5), 158(b)(3)$ (1952).

158. "Section 8 enumerates unfair labor practices; these may in some instances become relevant to the validity or interpretation of a collective agreement. Certain procedural safeguards are placed about the collective bargaining agreement: an obligation to confer in good faith on questions arising under it; a duty to follow certain steps prior to terminating or modifying the agreement unilaterally ( $\$ 8(d), 204(a)(2)$ ). And a limited number of substantive rights conferred under the Act may incidentally involve the interpretation of the collective agreement. (E.g., $\$ 9$ (a).)" Association of Westinghouse Salaried Employees v. Westinghouse Elec. Corp., 348 U.S. 437,443 n.2 (1955).

159. See note 135 supra.

160. Sec, e.g., Shirley-Herman Co. v. International Hod Carriers, 182 F.2d 806 (2d Cir. 1950). 1953).

161. See Textile Workers Union v. American Thread Co., 113 F. Supp. 137 (D. Mass.

It can be argued that the federal forum is analogous to the federally-chartered bants in Osborn v. Bank of the United States, 9 Wheat. 738 (U.S. 1824). Sec generally HART AND Wechsler, The Federal Courts and the Federal System 733-47 (1953); Mishlin, The Federal "Question" in the District Courts, 53 CoL. L. REv. 157, 184-96 (1953). Another 
While the argument for the constitutionality of a protective jurisdiction seems persuasive, there has been no indication by the Supreme Court that it will be accepted. The alternative, however, should not be to give Section $30 \mathrm{x}$ a substantive reading in order to find it constitutional, as some of the lower federal courts have done. ${ }^{102}$ The Court, in the face of a contrary congressional intention, should not create federal labor policy with the extensive impact upon traditional state power here outlined.

analogy suggested by these authors is the federal bankruptcy program. See Williams $\mathbf{v}$. Austrian, 331 U.S. 642 (1947); Schumacher v. Beeler, 293 U.S. 367 (1934).

In National Mut. Ins. Co. v. Tidewater Transfer Co., 337 U.S. 582, 594 (1949), Mr. Justice Jackson also drew an analogy to the bankruptcy program: "Congress also is given power in Art. I to make uniform laws on the subject of bankrupteies. That this, and not the judicial power under Art. III, is the source of our system of reorganizations and bankruptcy is obvious ...."." 1949).

162. E.g., Wilson \& Co. v. United Packinghouse Workers, 83 F. Supp. 162 (S.D.N.Y. 